\title{
A COVID-19 JÁRVÁNY IDŐBELI ALAKULÁSÁNAK VIZSGÁLATA SZIGMOID GÖRBÉKKEL
}

\author{
Szabó Ferenc János \\ egyetemi docens, Miskolci Egyetem, Gép-és Terméktervezési Intézet \\ 3515 Miskolc, Miskolc-Egyetemváros, e-mail: machszf@uni-miskolc.hu
}

\begin{abstract}
Absztrakt
A szigmoid görbék az élet különbözö jelenségeinek leirására alkalmasak, nagyon széles alkalmazhatósági területtel. A COVID-19 nevü (további elnevezései: nCoV-2019, SARS-COV-2), újtípusú koronavirusos megbetegedések számának, valamint az ebben a betegségben elhunytak számának idöbeli alakulása szintén szigmoid alakú görbét ír le. A görbének három fö szakasza különithetö el, az elsö a korlátlan növekedés, a második a korlátozott növekedés és a harmadik a telitödés szakasza. Mivel a megbetegedésnek, annak időbeli alakulásának szerves részesei voltunk, ezért mindhárom szakasz mindannyiunk számára személyesen is megfigyelhetö és átélhetö volt. A megbetegedések és halálozások számának alakulását jelen cikkben Kina (Wuhan, halálozások, 2020 január 17-töl május 30-ig), Olaszország (halálozások, 2020. február 22- töl július 12-ig), valamint Magyarország (fertözöttek 2020. március 4töl július 12-ig) és Magyarország (halálozások 2020. március 15-töl július 12-ig) hivatalosan jelentett számainak napi alakulását detektálva felvehetö görbékkel vizsgáljuk, ezek mindegyike logisztikai görbe, melyek szintén szigmoid alakúak. A görbék minél részletesebb ismeretére alapozva alkalmazható az utóbbi években kifejlesztésre került EBSYQ nevü (Evolutionary Based System for Qualification of Group Achievements) görbe-analizis módszer, amely minden, szigmoid görbével jellemezhetö növekedési és telitödési jelenség vizsgálatára alkalmas, söt felhasználható a görbék ismeretében a vizsgált jelenség jövőbeli alakulásának vizsgálatára, elörejelzésre is. A több örszág adataiból elöálló görbék összehasonlitására a módszer kiválóan alkalmas, ezekböl az összehasonlitásokból további, érdekesnek igérkezö következtetések vonhatók le.
\end{abstract}

Kulcsszavak: szigmoid görbék, logisztikai görbe, COVID-19, pandémia, EBSYQ módszer

\begin{abstract}
Sigmoid curves are ables to describe several phenomena of our life, they have extremely large and wide application fields. The number of contaminated persons and deaths because of the COVID-19 (other names: $n C o V-2019$, SARS-COV-2) in function of the time are also sigmoid shape curves. These curves have three important characteristic parts: first part is the „overwhelming” growth, or nonlimited growth, the second part is when the growth is limited or disturbed and the third part is a saturation part. Since we were living personnally the COVID-19 pandemic, for all of us was observable all the three characteristic parts of the curves. In this paper the number of the deseases and deaths is investigated on the basis of the officially presented numbers by China (Wuhan, deaths, from 17th of January until 30th of May 2020), Italy (deaths, from 22nd of February until 12th of July, 2020), Hungary (deseases, from 4th of March until 12th of July, 2020) and Hungary (deaths, from 15th of March until 12th of July, 2020), by detecting the numbers every day and this way building the curves. All these curves are sigmoid shape curves, so called logistic curves. On the basis of the better knowledge of these curves, it is possible to apply the recently developed EBSYQ (Evolutionary Based System for Qualification of Group Achievements) curve analysis system, which is able to compare and analize
\end{abstract}


every phenomena having growth or saturation behaviour. It is able also to predict the future of these cases. Comparing the data of several countries, it could be possible to derive interesting conclusions.

Keywords: Sigmoid curves, logistic curve, COVID-19, pandemic, EBSYQ system

\section{Bevezetés}

A Szigmoid (s- alakú) görbéket az 1700-as végére tehető felfedezésük óta az élet nagyon sok területén alkalmazzák, föleg olyan jelenségek leírására és vizsgálatára, melyekben jelentős szerepet játszik a növekedés, illetve ennek a növekedésnek valamilyen okból való korlátos volta, esetleg leállása (pl. egy állat- populáció létszámának növekedése, amit a ragadozó megjelenése és az általa előidézett létszámcsökkenés korlátozhat, sőt megállíthat). A növekedés leállását telítődésnek is nevezhetjük, ennek is többféle jelentése lehet a vizsgált jelenség természetének függvényében (pl. a sport- világcsúcsok száz éves történetét nézve, Szabó (2011) [1], egyre kisebb növekedés tapasztalható az idő előrehaladtával a világcsúcs- eredmény számértékének alakulásában, mivel egyre közelebb kerülünk az emberi teljesítőképesség végső határához, ami szintén telítődés- jellegü növekedés- lassulást okoz, vagy egy termék életét végigkövetve a piac kezdeti felfutását, növekedését később a piac telítődése váltja fel, ami a növekedés csökkenését, leállását okozza). Nagyon részletes és érdekes „state- of - the- art” jellegü összefoglaló található Rézsó Ferencné (2020) [2] munkájában a szigmoid görbék felfedézéséröl, különféle területeken történt alkalmazásairól, jelentősebb továbbfejlesztéseiről, módosításairól.

A szigmoid görbéknek vírus, vagy baktérium tenyészetek növekedésének, járványok terjedésének leírására való alkalmazására találhatunk példát Kovács Róbertné (2019) [3] baktériumtenyészettel és szennyvízkezeléssel foglakozó cikkében. A járványok terjedésének gráfok segítségével történő vizsgálata során Besenyei és Bodó (2017) [4] szintén szigmoid jellegü görbét mutat be a járványterjedés modellezésére. Szegedi matematikusok megalkották a Zika- vírus terjedésének matematikai modelljét (Dénes et al., (2019), [5]). Ezek az érdekes és jelentős eredmények alátámasztják, hogy a szigmoid görbék segítségével jól leírhatók a vírusok, baktériumok növekedése is és az általuk okozott járványok is vizsgálhatók szigmoid görbék segítségével. Jelen cikkben szereplő vizsgálataink egyik célja az, hogy bebizonyítsuk, hogy a szigmoid görbék alkalmasak az új típusú koronavírus járvány terjedésének és halálozási számainak leírására is, valamint az EBSYQ módszer szempontjai alapján (Szabó, (2017), [6]) analíziseket végezzünk a járvány szigmoid görbéire vonatkozóan, majd ezekböl következtetéseket vonjunk le, föleg az előrejelezhetőséget illetően. A görbék alapján történő előrejelezhetőségre vonatkozó eredményeket nagyon jól lehet majd hasznosítani a multidiszciplináris optimálás területén, mivel az ott alkalmazott optimumkereső algoritmusok iteráció történeti görbéje szintén mindig szigmoid jelleget mutat (Szabó, (2018), [7]).

Az 1. táblázatban többféle szigmoid alakú görbe látható. A táblázat ábrái alapján alapvetően kétféle jellemző alak különíthető el: az egyik jellemző alak a csak növekedést mutató alak (növekedési görbe), amely két fö szakaszt mutat, az egyik a gyors növekedés szakasza, a másik pedig a telítődés szakasza. A másik jellemző alak, a szigmoid alak esetén a görbe kezdetén egy visszahajló szakasz található, amelyet ha képzeletben meghosszabbítunk, akkor egy nagyon meredek, gyors, szinte minden határon túli növekedést (exponenciális függvény) mutató esetet látnánk, amely később csillapodik, sőt a harmadik szakaszban szintén telítődik, esetleg leáll. Ezt a görbét nevezik logisztikai görbének. Jelen cikkben ezt a két görbetípust fogjuk a valós görbék közelítésére felhasználni, majd a regressziós tényező értéke alapján a jelenséget jobban közelítő görbefajtát kiválasztani a további vizsgálatokhoz. Létrehozójuk, elnevezőjük tiszteletére a logisztikai görbét Pearl- Reed (1920), [8] görbének, a növekedési görbét Bertalanffy (1960), [9] görbének fogjuk nevezni. 
1. táblázat. Többféle szigmoid görbe

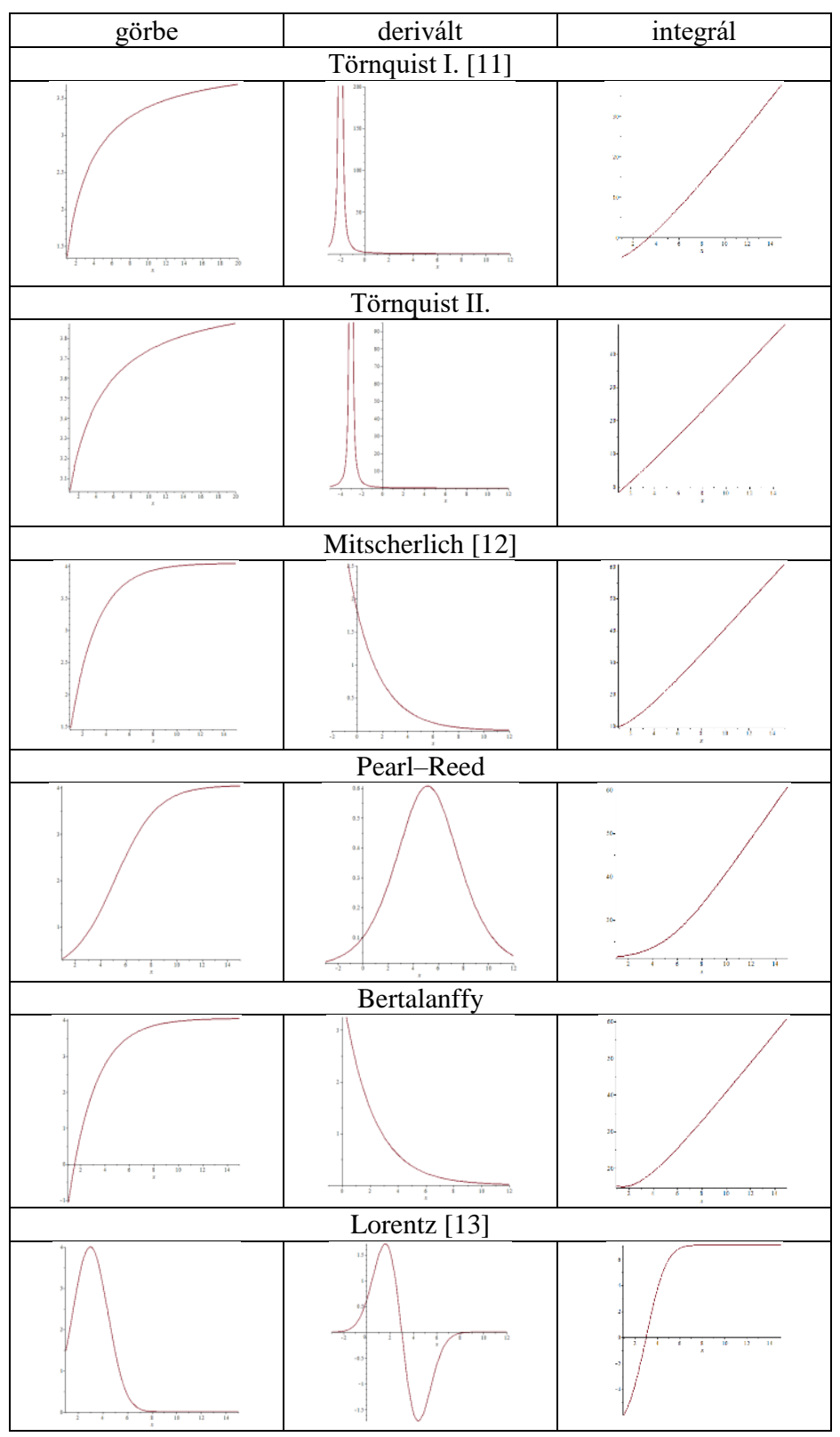

A szigmoid görbék alakja erősen nemlineáris, föleg az első és a harmadik szakaszban jelentősen eltér a lineáris alaktól, ami megnehezítheti a regressziós tényező meghatározását, mivel az irodalomban a lineáris regressziós tényező található meg legkönnyebben. Ez a helyzet úgy oldható fel, hogy egy transzformációval a görbét lineáris görbévé alakítjuk és a transzformált görbére számoljuk a regressziós tényezőt. Ez a transzformáció, a létrehozók tiszteletére a Fisher- Pry (1971), [10] transzformáció nevet kapta. A Fisher- Pry transzformáció lényege, hogy alkalmazva a $\mathrm{F}=\mathrm{N} / \mathrm{K}$ transzformációt, akkor 
$\ln (\mathrm{F} /(1-\mathrm{F}))=\mathrm{rt}+\mathrm{b}$, tehát a logisztikus függvény helyett egy olyan egyenest kapunk, melynek $\mathrm{r}$ a meredeksége . Az egyenesre pedig már könnyen kiszámítható a regressziós együttható.

Ha a regressziós együttható abszolút értéke közel esik 1-hez, akkor jó a közelítés minősége, és minél kisebb, annál rosszabb a közelítés. Ha értéke pozitív, akkor növekedésről van szó, ha negatív, akkor csökkenésről. Néha a regressziós tényező nélkül is eldönthető, hogy melyik fajta görbe írja le jobban a jelenséget, hiszen esetleg könnyen látható, hogy hiányzik az első, zavartalan fejlődést mutató szakasz és így csak növekedés van, ekkor növekedési görbe fog jobban közelíteni, egy másik esetben pedig lehet, hogy hangsúlyos a kezdeti zavartalan növekedés szakasza és akkor a logisztikai görbe közelít majd jobban.

A napok során felvett adatokból elóálló függvényeket egy approximációs módszerrel a legkisebb négyzetek elve alapján szigmoid függvénnyel közelítjük. A görbék egyenletében szereplő három paramétert $(K, r, c)$ tervezési változónak tekintve, keressük a valós és a közelítő függvény eltéréseiből számolt négyzetösszeg minimumát, ezzel egy három változós optimumkeresési feladatot definiálunk. Ezt az optimumkeresési feladatot a Nelder- Mead (1965), [14] optimumkereső algoritmussal oldjuk meg, így határozható meg a három paraméter legjobb értéke, ami mellett ez a négyzetösszeg minimális. Az approximáció elvégzése után a paraméterek birtokában felépíthető a görbék egyenlete, képezhető a görbék deriváltja és integrálja is.

A görbék egyenletei: Pearl- Reed : $y=\frac{K}{1+c e^{-r x}}$, és Bertalanffy: $y=K\left(1-c e^{-r x}\right)$. A görbék egyenletében lévő paraméterek értékeit az elérhető legkisebb eltérések esetére a 2. táblázat tartalmazza. (Kína, Wuhan, halálozások görbéje esetére).

2. táblázat. A közelitö függvényekben szereplö paraméterek

\begin{tabular}{|l|c|c|c|c|}
\hline & $\boldsymbol{K}$ & $\boldsymbol{r}$ & $\boldsymbol{c}$ & regr. tényezö \\
\hline Pearl-Reed & 3300 & 0,1725 & 191,21 & 0,99439 \\
\hline Bertalanffy & 3763 & 0,0388 & 1,688 & 0,97657 \\
\hline
\end{tabular}

A 2. táblázat alapján eldönthető, hogy az adott esetben a Pearl- Reed függvény írja le a jelenséget pontosabban, tehát a logisztikai görbét alkalmazzuk majd a további vizsgálatokhoz. Mivel a többi vizsgált esetben is nagyon hasonló a görbék alakulása, ezért a továbbiakban az összes többi itt vizsgált esetre is a Pearl- Reed függvényt alkalmazzuk. Ezekre a görbékre a $K, r, c$ paraméterek értékei a 4. táblázatban láthatók. A logisztikai függvény alkalmas annak a jelenségnek a követésére is, ami a gyakran emlegetett visszatérő járvány, azaz a második hullám esetén jönne létre, hiszen a szakirodalomban találhatók példák kéthullámos (bilogisztikus függvény), vagy háromhullámos (trilogisztikus függvény) esetre is, sőt lehetséges a multilogisztikus, sokhullámos jelenségek leírása is Meyer, Turner editors (1994), [15].

\section{A COVID-19 járvány görbéinek analízise}

Jelen munka során Kína (Wuhan, halálozások, 2020 január 17-től május 30-ig), Olaszország (halálozások, 2020. február 22- től július 12-ig), valamint Magyarország (fertőzöttek 2020. március 4-től július 12-ig) és Magyarország (halálozások 2020. március 15-től július 12-ig) hivatalosan jelentett számainak napi alakulását detektálva felvehető görbéket vizsgáljuk. Az adatokra a Nelder- Mead módszer alkalmazásával logisztikai (Pearl- Reed) görbéket feszítettünk (1. ábra). A vízszintes tengelyen a vizsgált napok száma látható. 
A logisztikai görbe első szakasza annak az esetnek felel meg, amikor a növekedés teljesen zavartalan, ekkor exponenciális görbe mentén, nagyon meredeken emelkedik a megbetegedések száma. Ezt a szakaszt külön is modelleztük, exponenciális görbével, melynek egyenlete: $\mathrm{y}=\mathrm{kx}^{\mathrm{n}}, k$ és $n$ értéke az egyes görbékre a 3. táblázatban látható. Ez a zavartalan növekedési szakasz a vírus szempontjából a megjelenés után azonnal beindul és elkezdődik a gyors növekedés, ami mindaddig tart, amíg nem jelentkeznek a virológus, járványügyi, katasztrófavédelmi, orvosok, ápolók és egyéb, ide kapcsolódó szakemberek által foganatosított intézkedések hatásai. Ekkor az intézkedések olyan hatással fognak járni, mintha egy egér- populációba, ami eddig zavartalanul szaporodott, beteszünk pár macskát, azaz ragadozót. A populációban megszünik a robbanás- szerủ gyors növekedés, és elindul egy önszabályozó, a végén telítődő, azaz egyensúlyba kerülő növekedési helyzet. Ezért nagyon fontosak a szakemberek által hozott intézkedések, és azok minél szorosabb betartása, követése, mert ez a vírus szempontjából úgy jelentkezik, mint a ragadozó megjelenése. A görbéken bejelöltük ezt a kezdeti gyors növekedésü szakaszt is, ha ezt gondolatban meghosszabbítjuk, látható, hogy milyen hatalmas számú embertömeget mentettek meg ezek az intézkedések, a szakemberek munkája, és a fertőzések, halálozások száma hogyan lassult. Ez a lassú, 'lapos' görbe főleg a Magyar halálozások számának alakulásában látható. Ennek a görbének a laposan tartásában mutatkozik meg annak a hősies munkának az eredménye, amit a magyar szakemberek végeztek.
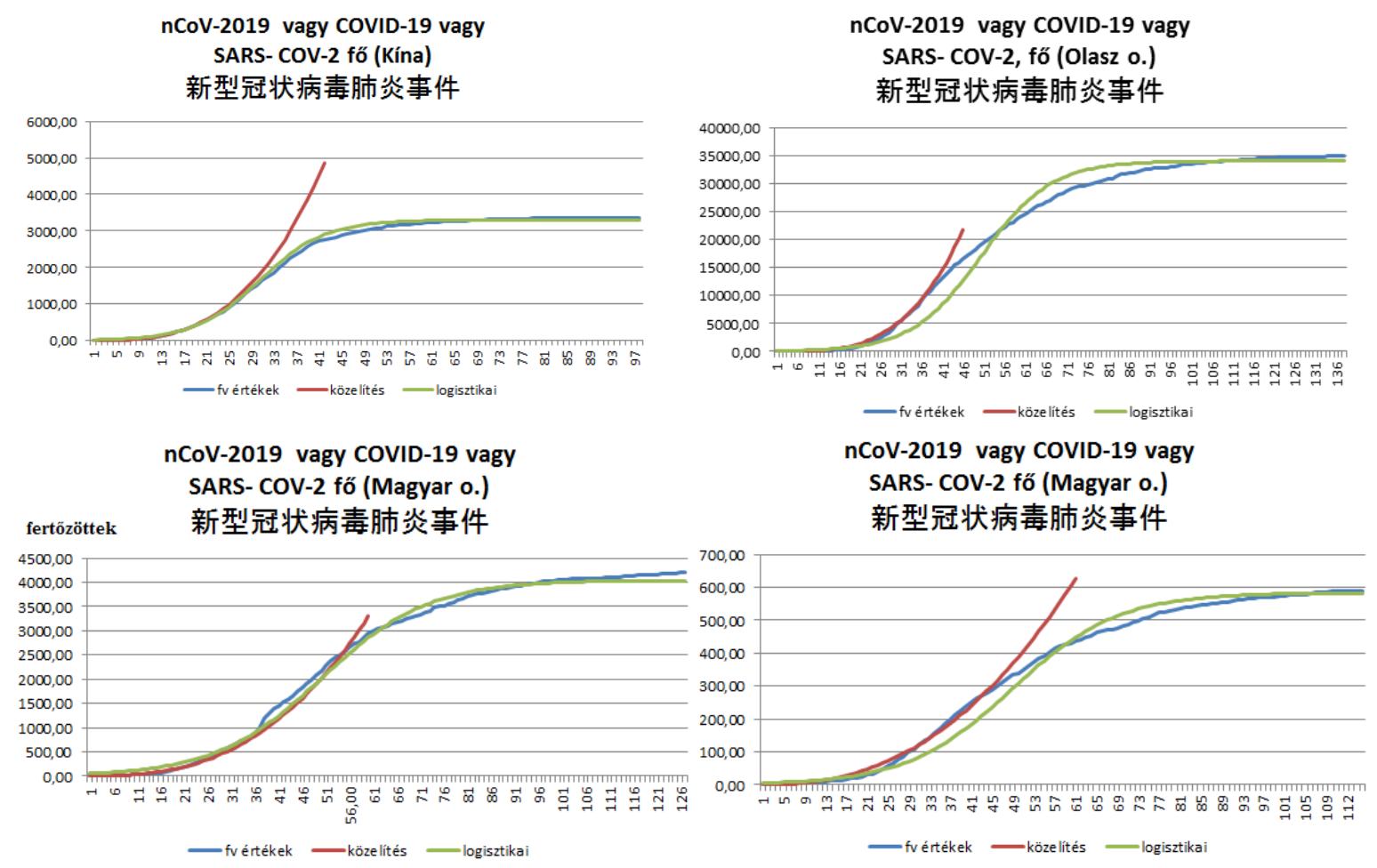

1. ábra. Az adatok alapján létrehozható görbék és közelitésük

Emellett meg kell említeni a magyar lakosság fegyelmezett együttmüködését is, ami hozzájárult ennek a munkának a hatásosságához. A piros görbe gondolatbeli meghosszabbítása alapján elképzelhető, 
mennyi ember halhatott volna meg ezek nélkül az eredmények nélkül. A jelen cikk írásakor, 2020 július közepén még nagy mértékben tombol a járvány első hulláma a világban több országban is, tehát mindenki saját szemével is láthatja, hogy egyes országokban, ahol nem történtek ilyen intézkedések, vagy pedig a lakosság nem tartotta be azokat olyan fegyelmezetten, mint Magyarországon, milyen tömeges méretủ elszaporodás, tömeges járvány és milyen nagyszámú halálozás alakulhat ki.

3. táblázat. A görbék exponenciális közelitésének paraméterei

\begin{tabular}{|c|c|c|}
\hline görbe & $\boldsymbol{k}$ & $\boldsymbol{n}$ \\
\hline Kína & 0,0523 & 3,06 \\
\hline Olasz o. & 0,043 & 3,45 \\
\hline Magyar fertözöttek & 0,0522 & 2,70 \\
\hline Magyar & 0,031 & 2,42 \\
\hline
\end{tabular}

Azon a görbeszakaszon, ahol a zavartalan növekedési fázistól eltér a görbe, megtalálható a logisztikai görbe inflexiós pontja, ezután már nem zavartalan a fejlődés, hanem a korlátos növekedés szakasza lesz jellemző. Ez a közelítések és az esetleges előrejelzések szempontjából nagyon fontos, mivel az inflexiós pont elött, hiába sikerül szorosan ráfeszíteni a közelítő görbét az addig rendelkezésre álló adatokra, a jelenség nem viseli még a szigmoid jelleget, csak a korlátlan növekedés jegyeit hordozza, tehát szigmoid görbe alapján nem ,jósolható" meg a jövő, azaz nem szabad a telítődésre, az egyensúly beállásának idejére, a tetőzés mértékére vonatkozó kijelentéseket tenni. Az inflexiós pont megjelenése után azonban megjelennek a szigmoid jellegre utaló jegyek, és ahogy az időben minél jobban távolodunk az inflexiós ponttól, a továbbiakban annál pontosabb elörejelzéseket fogunk tudni adni arra nézve, hogy a jelenség a jövőben hogyan viselkedhet. A kínai görbe esetén a 33. nap tájékán a görbe alapján már megmondható volt, hogy hozzávetőleg mikor és milyen magas esetszámmal fog „egyensúlyba kerülni” a járvány, amit a későbbi híradások be is igazoltak ( ez kb. a 80. nap tájékán következett be). Tehát majdnem 50 napra lehetett elöre jósolni a görbe alapján. A szigmoid görbék tulajdonságainak ismeretére épülő, ilyen nagy ívü, jelentősen előrenyúló előrejelzéseknek a különböző helyzetekre, változásokra való hatékonyabb felkészülésben, az események előrelátásában, alakulásának mélyebb megértésében mutatkozhat meg a haszna, az élet különböző területein.

Ezekkel a kijelentésekkel és előrejelzésekkel azonban mindig óvatosan kell bánni, mivel mindig fennáll a lehetősége, hogy olyan nem várt események történhetnek, amik teljesen elronthatják a görbe viselkedése alapján várt vagy felvázolt képet. Ilyen volt például a néhány idősotthonban kialakult helyzet, amely pár napig, amíg a megfeleló intézkedéseket meg nem hozták, majdnem visszahozta a megbetegedések számának zavartalan növekedését. A magyar fertőzöttek görbéjén ez a jelenség jól látható, a 35-50 napok közötti szakaszán. Mivel a betegségben a halálozások száma a megfertőződöttek számának mintegy 3- 5\%-a, ezért ez az eltérés a magyar halálozások görbéjén nem szembetünő. A napi adatok alapján adódó görbék egyébként elég „rücskösek”, egy-egy adott időszakban akár ijesztő eltéréseket, anomáliákat is mutathatnak, amik az előrejelzések szempontjából az adott pillanatban nagyon zavaróak lehetnek.

$\mathrm{Az}$ 1. ábrán látható görbék közül a piros görbék mutatják a korlátlan, zavartalan terjedés esetét, ez történne akkor, ha nem csinálnának semmit a szakemberek. A kék görbék mutatják a naponta közölt adatokat és az ezekből összeálló görbét, ez a „valós” görbe. A zöld görbék pedig a valós görbéket közelítő szigmoid görbék, melyeket a legkisebb ngyzetek elvére alapozott approximációs módszerrel alkottunk meg. A közelítő szigmoid görbék egyenleteiben szereplő paraméterek értékei a 4. táblázatban láthatók. A táblázatban feltüntettük a görbe inflexiós pontjának megjelenését jelölő napot is. 
4. táblázat. A valós adatokat közelítö szigmoid görbék paraméterei

\begin{tabular}{|c|c|c|c|c|}
\hline görbe & $\boldsymbol{K}$ & $\boldsymbol{r}$ & $\boldsymbol{c}$ & inflexiós pont helye [nap] \\
\hline Kína & 3300 & 0,1725 & 191,24 & 25 \\
\hline Olasz o. & 34000 & 0,1192 & 397,91 & 45 \\
\hline Magyar & 584 & 0,0987 & 124,66 & 43 \\
\hline Magyar fertözöttek & 4043 & 0,0883 & 83,29 & 50 \\
\hline
\end{tabular}

A görbék egyenletében szereplő paramétereknek fontos jelentései vannak. A $K$ paraméter az elért legmagasabb értéket jelenti, amit a növekedés elérhet az egyensúly kialakulásakor, a folyamat végén. A jelen munkában vizsgált esetben ez a megbetegedések, illetve a halálozások számának elérhető legmagasabb értékét mutatja. A $K$ paraméter a járványügyi szakemberek számára nagyon fontos jellemző, mivel az általa mutatott esetszám- maximum a szakemberek számára arra enged következtetni, hogy mennyire várható az egészségügy terheltsége a nagy számú fertőzések esetén, illetve a halálozásra utaló görbe maximuma alapján megbecsülhetö, hogy mennyi olyan eszközre lesz szükség, ami a súlyosabb esetek ellátásához kell (pl. lélegeztető gép), tehát tervezhetők a szükséges beszerzések, ágyszám- felszabadítások, kórházi helyek létrehozása, ápolók, orvosok szükséges számának tervezése, védőeszközök, gyógyszerek beszerzése, stb. A növekedési folyamat gyorsaságát az $r$ paraméter fejezi ki, ha ez minél nagyobb értékü, akkor a növekedés, azaz esetünkben a járvány terjedése annál gyorsabb, meredekebb. A harmadik, $c$ paraméter egy úgynevezett pozíció- paraméter, azaz ennek a paraméternek a változásai a görbének a helyzetét fogják csak megváltoztatni. Ha ez a paraméter minél kisebb, akkor a görbe balra tolódik, azaz minden gyorsabban, hamarabb játszódik le. Ha nagyobb, akkor jobbra tolódik a görbe és minden később következik be. Ez talán a bevezetett intézkedések „kíméletességével" lehet kapcsolatban a járvány esetén, hiszen a gyors, aggresszív beavatkozások hatása hamarabb megmutatkozik, a később bevezetett, kíméletesebb, „puhább” intézkedések később hozzák meg a látható eredményeket is. Az intézkedések hatásosságával lehet kapcsolatban az inflexiós pont megjelenésének helye is, hiszen ha hamarabb jelenik meg az inflexiós pont, akkor a korlátlan fejlődéstől az intézkedések hatásai hamarabb térítik el a fejlődést, a később megjelenő inflexiós pont a később meghozott intézkedések miatt lehetséges, vagy esetleg az okozza, hogy később jelentkezik ezek hatása. A későbbi inflexiós pont esetén hosszabb ideig érvényes a zavartalan fejlődés meredek növekedési szakasza, ezért nagyobb esetszám várható.

A cikk írásának idején, 2020 július közepén az 1. ábra görbéi az egyensúlyi állapot közelében voltak, vártuk az első hullám végét. A magyar halálozások száma esetén volt olyan, hogy 4 napon keresztül nulla volt, és a fertőzöttek száma is kevés volt. Mégsem dőlhettünk hátra teljesen gondtalanul, mert a világban a járvány nagy erővel tombolt, a Magyarországot körülvevő országokban is az intézkedések egyre jelentősebb feloldása, lazításai miatt újabb gócok alakultak ki, száz fölötti esetszámokkal. Ez a nyári időszak miatt, a turizmus újra beindulásával, utazásokkal sajnos egyre több veszélyt rejtett magában. A magyar szakemberek újabb szigorítások bevezetését fontolgatták. 2020. július 12-én szigorítottak a külföldiek Magyarországra történő belépésének szabályain, az országokat piros, sárga zöld kategóriákba sorolva. Az 1. ábrán a magyar fertőzöttek görbéjén megfigyelhető, hogy a valós görbe vége „nem ül le” teljesen. Ha a járvány elmúlta bekövetkezett volna, akkor már vízszintesnek kellene lenni ennek a szakasznak, de lassú emelkedés látható. Ez ad okot az aggodalmakra és a második hullámtól való félelemre, hiszen ha ez a növekvő tendencia folytatódik, akár át is csaphat az exponenciális növekedésbe is. Ha megjelenne a második hullám, a görbék eddigi ismeretében arra kell felkészülni, hogy az exponenciális, meredek növekedés szakaszával fog újra „berobbanni”, a telítődést is tartalmazó második szakasz csak az újabb intézkedések hatásossága esetén indulhat majd be. Ha a máso- 
dik hullám is eléri majd az inflexiós pont szakaszát és ezután eltelik egy kis idő, akkor újra meg lehet majd próbálni „megjósolni”, előre jelezni a maximális esetszámot, ennek várható elérési idejét, a növekedés sebességét, stb.

A görbék lefutásának jellemzői, az egyenletükben szereplő paraméterek ilyen értelmezései, az ezek alapján levonható következtetések, összehasonlítások képezik az EBSYQ módszer lényegét. Ezzel a görbe- analízis rendszerrel vizsgálni és minősíteni lehet, számszerủen kimutatható különbségek alapján akár objektíven rangsorolni is lehet a szigmoid görbével leírható jelenségeket, csoportok teljesítményét, pályázatra jelentkezők eredményeit, és nagyon korrekt, objektív, számszerüen kimutatható különbségek alapján rangsorolhatók, minősíthetők a vizsgált csoportok, egyének, jelentkezők, jelenségek. Bár az EBSYQ módszer alkalmas lenne rá és a görbékből kinyerhető adatok ezt lehetővé is tennék, de jelen munkában nem célunk az egyes országok járványügyi tevékenységének ilyen összehasonlítása és minősítése. Az eddigi vizsgálatokból és paraméterekből azonban világosan látható, hogy a magyarországi intézkedések kíméletesek, de hatásosak voltak, a görbék „laposak”, ami kis esetszámokat eredményezett a többi ország adataihoz képest. Ezek az eredmények azt mutatják, hogy a magyar intézkedések optimális időben és hatékonysággal lettek foganatosítva, a lakosság együttmüködésének köszönhetően pedig optimálisan kifejtették jótékony, védő hatásaikat.

Az itt bemutatott vizsgálati, összehasonlító folyamat folytatható a görbék deriváltjainak és integráljának vizsgálatával és paramétereik további összehasonlításával, ami remélhetőleg további részletekre világít majd rá és további következtetések, előrejelzési lehetőségek felfedezését teszi lehetővé.

\section{A görbék deriváltjának és integráljának vizsgálata}

A vizsgálatokhoz használt Pearl- Reed logisztikai görbe deriváltjának egyenlete: : $\frac{d y(x)}{d x}=\frac{k c r e^{-r x}}{\left(1+c e^{-r x}\right)^{2}}$, az integrálja pedig a következőképpen számolható: $\quad \int y(x) d x=-\frac{K}{r} \ln \left(e^{-r x}\right)+\frac{K}{r} \ln \left(1+c e^{-r x}\right)$.

Az ezekben szereplő $K, r, c$ paraméterek ugyanazok, amiket a görbék közelítéséhez használtunk, tehát értékükre továbbra is a 4. táblázat adatai érvényesek. Az 1. ábra logisztikai görbéinek (zöld görbék) derivált és integrál görbéje a 2. -5. ábrákon látható.

A logisztikai görbe deriváltja a növekedési sebességgel hozható kapcsolatba. Ez egy harang alakú görbe, megtalálható a maximuma, így látható, hogy mikor volt a folyamat ,tetőpontja”, azaz mikor volt a legnagyobb a növekedési sebesség. Ez az inflexiós pont környékén kell, hogy legyen, mivel az inflexiós pont után az intézkedések hatására csökkenni fog a járvány növekedési sebessége. Ez azt is jelenti, hogy abban az esetben, ha esetleg nehéz megtalálni vagy beazonosítani az inflexiós pont helyét, akkor a görbe deriváltját megnézve ez könnyen megtalálható, beazonosítható lesz. A folyamat végén, amikor az esetszámok a nulla érték felé közelítenek, a növekedési sebesség is leáll, tehát jó visszajelzés lehet az egyensúlyi állapot közelségére nézve, ha a növekedési sebesség görbéjében is a leállás- közeli állapot jelenik meg. Összehasonlításokra adhat lehetőséget, ha megvizsgáljuk, hogy az egyes folyamatokban milyen nagy a növekedési sebesség maximuma, azaz a „legmélyén” a folyamatnak milyen esetszám- növekedés fordulhatott elő, valamint megvizsgálható, hogy az egyes folyamatok esetén milyen hamar következett be a legnagyobb növekedési sebesség, ami a folyamat gyorsaságával, a lefolyási sebesség alakulásával van kapcsolatban. 
Szabó, F.J.

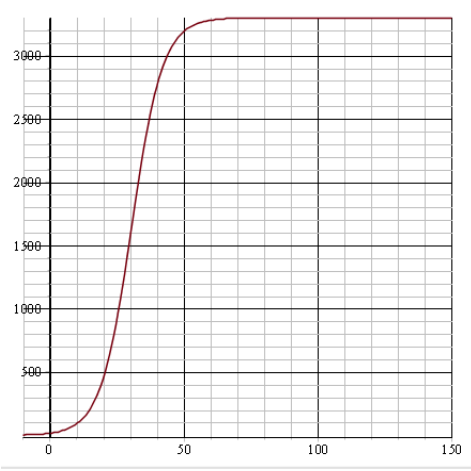

A COVID-19 járvány időbeli alakulásának vizsgálata szigmoid görbékkel
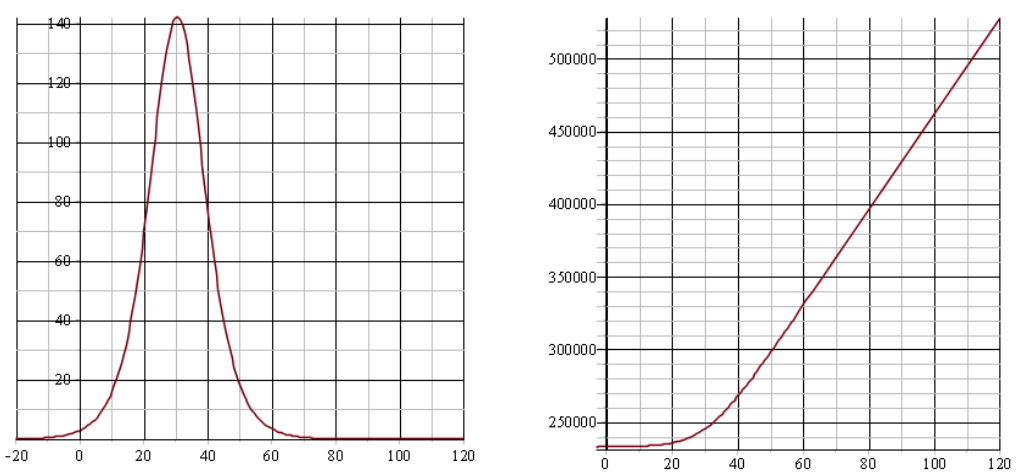

2. ábra. A kínai görbe, valamint deriváltja és integrálja
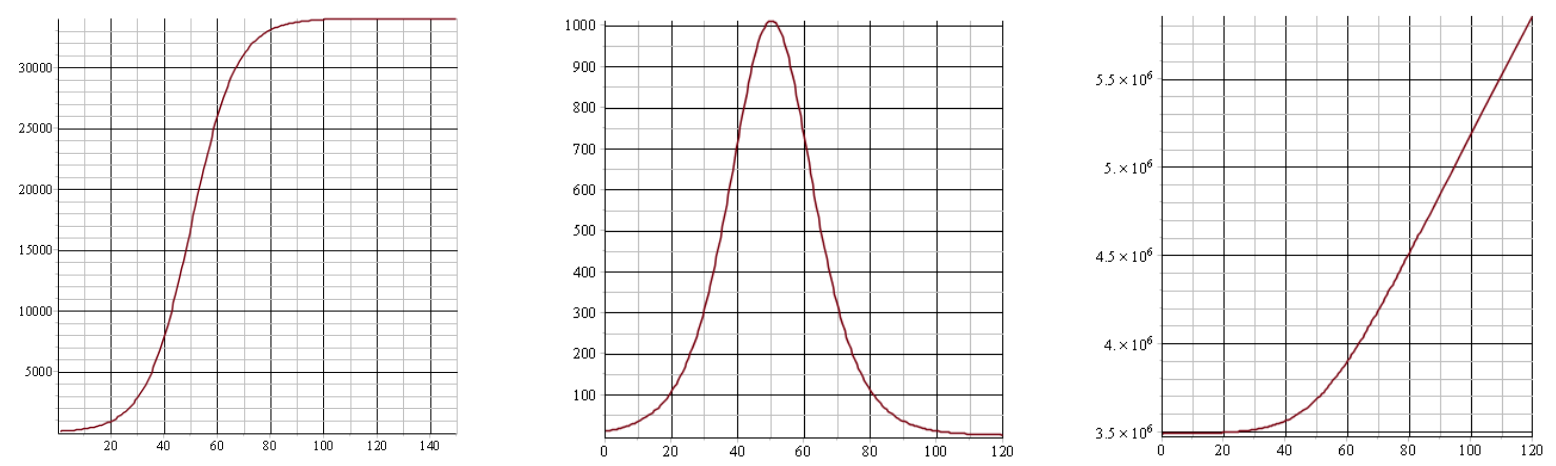

3. ábra. Az olasz görbe, deriváltja és integrálja
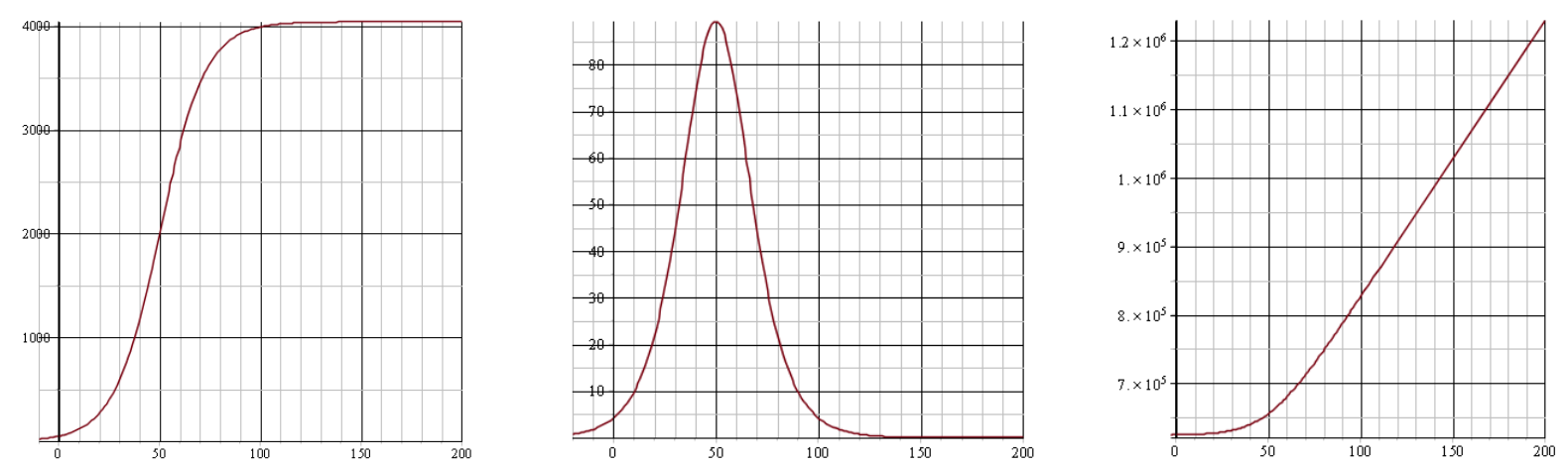

4. ábra. A magyar fertözöttek görbéje, valamint deriváltja és integrálja 

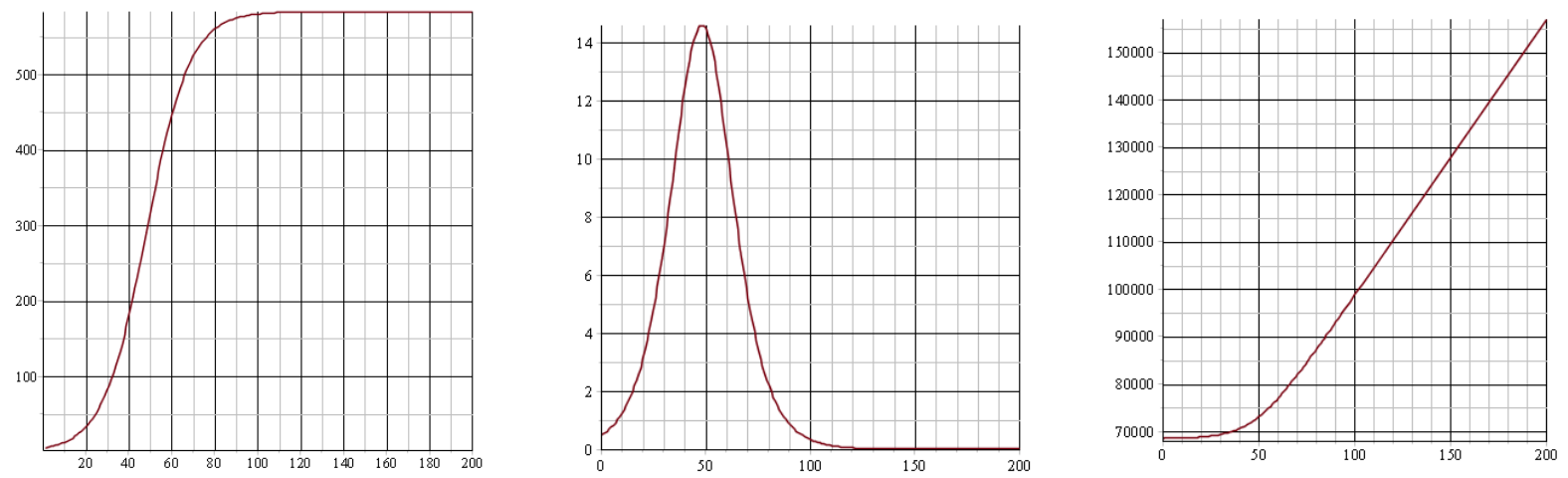

5. ábra. A magyar görbe, deriváltja és integrálja

A logisztikai görbe deriváltjának harang alakja esetén fontos jellemzö, hogy a maximum hol található (a megjelenés után hány nappal), hiszen a maximális növekedési sebesség kialakulásának időszükséglete utal a járvány terjedési sebességére, a folyamat gyorsaságára, „robbanás”- szerüségére. A másik fontos jellemző a maximum felénél felvett szélesség. A 2. - 5. ábrákon látható, hogy az egyik harang- görbe (pl. a kínai görve) keskenyebb, „hegyesebb” alakú, mint egy másik (pl. magyar elhunytak görbéje). Ezt a különböző tudományterületeken (rezgéstan, villamosság, stb.) gyakran fontos jellemzőnek tartják és a görbe maximumának fele magasságában vett szélességgel hasonlítják össze. Van, ahol nem a fele magasságban, hanem a 0.717 értéknél, az effektív értéknél veszik, pl. a villamosságban, és van, ahol ezt a szélességet elosztják a maximum fellépésének helyével, ekkor a csillapítási tényezőt kapják meg, pl. a rezgéstanban. Esetünkben a járvány maximális sebességének „,kiterjedésére", tartósságára utal a fél-maximumnál vett szélesség, ez is a járvány erősségét jellemzi, hiszen ha sokáig tart a nagy növekedési sebesség, akkor nagy esetszám várható, ha kevésbé kiterjedt a maximális sebesség érvényessége, akkor kisebb esetszámot, azaz hamarabbi lecsengést várhatunk. Erre a jellemzőre a „szignifikancia”- faktor elnevezést javaslom, mivel ez a maximális sebesség hangsúlyosságát, szignifikanciáját mutatja. Tehát a szignifikancia faktort úgy határozzuk meg, hogy a fél maximum magasságában mért haranggörbe- szélességet elosztjuk a fellépés helyével. A szignifikancia faktor kis értéke két dolgot jelenthet: vagy azt, hogy kicsi a maximális sebesség hatásának kiterjedése, vagy pedig később következik be. Mindkét eset azt jelenti, hogy a maximális sebesség kevésbé jelentős, kicsi a szignifikanciája, azaz ezeket jó jelként értelmezhetjük. A hamar fellépő növekedési sebesség- maximum jelentheti ugyan a terjedés gyorsaságát, de azt is magával vonja, hogy hamar elértük az inflexiós pontot, tehát az exponenciális növekedés kevésbé tudta kifejteni a jelentős mértékü esetszám- növelő hatását. Értelemszerüen a szignifikancia faktor nagy értéke azt jelentheti, hogy hamar, gyorsan fellép a maximum, vagy nagy a kiterjedése. Mindkét eset a maximális sebesség nagy jelentőségét támasztja alá, azaz a járvány erősségére, gyors növekedésére utal. A későn fellépő terjedési sebesség-maximum nem jó hírt jelentő jellemző, mert az azt is jelenti, hogy későn tudták elérni az inflexiós pontot, és addig az exponenciális növekedés még nagyobb esetszám- növekedést okozott. Ezért nem lehet felhötlenül örülni az olasz görbénél a kis szignifikancia faktor értéknek. A maximum fellépésének helyét, a maximum értékét, a fele maximumnál vett szélességet és a szignifikancia faktor értékét az 5. táblázatban foglaltuk össze.

A logisztikai görbe integráljának alakját tekintve látható, hogy ennek nagy részét egy egyenes alkotja. Ennek az az oka, hogy a logisztikai görbének is jelentős része a leállás, lecsengés időszakára jellemző konstans alak, aminek az integrálja egyenes. Az integrál görbének érdekesebb része a kezdeti 
görbeszakasz, ami a logisztikai görbe alatti területet jelenti. Az itt leolvasható számértékek az esetszámok naponta akkumulált növekedését mutatják, amit a járványügyi szakemberek szintén felhasználhatnak az egészségügy várható terheltségének becslésére, esetleg a szükséges eszközök mennyiségének felmérésére, a beszerzések előre tervezésére.

5. táblázat. A logisztikai görbe deriváltjának jellemzöi

\begin{tabular}{|c|c|c|c|c|}
\hline görbe & Maximum helye & Maximum értéke & $\begin{array}{c}\text { Fél maximumnál } \\
\text { a szélesség értéke }\end{array}$ & $\begin{array}{c}\text { Szignifikancia } \\
\text { faktor }\end{array}$ \\
\hline Kínai & 25 & 143 & 21 & 0,84 \\
\hline Olasz & 45 & 1010 & 30 & 0,47 \\
\hline Magyar & 43 & 14,5 & 33 & 0,77 \\
\hline $\begin{array}{c}\text { Magyar } \\
\text { fertőzöttek }\end{array}$ & 50 & 89 & 40 & 0,80 \\
\hline
\end{tabular}

Újra nagyon szembetűnően ,adja magát” a különböző görbék jellemzőinek számszerű összehasonlítása, a minősítés, rangsorolás lehetősége, valamint a görbék jellemzői nagyon jó lehetőséget is biztosítanának erre, de itt is szeretnénk hangsúlyozni, hogy a különböző országok járványügyi szakembereinek, munkájának összehasonlítása, minősítése, rangsorolása jelen dolgozatnak nem célja. Minden itt vizsgált ország járványügyi szakemberei áldozatos és a tőlük telhető legjobb munkával igyekeztek megfékezni a járvány terjedését, munkájuk hatékonysága a lakosság együttmüködésén, az intézkedések tömeges követésén, szoros, szigorú és következetes betartásán is múlott.

Az itt bemutatott vizsgálatokhoz a Johns Hopkins Egyetem (2020) [16] munkatársai által fenntartott, a világ összes országára hivatalos adatokat adó honlapon közölt adatokat használtuk fel, minden vizsgált görbét naponta fejlesztve. A vizsgálatok 2020 július közepén, a cikk beadásával fejeződtek be. Ekkor a szakemberek nagyon valószínủnek tartották, hogy hamarosan beindulhat a járvány második hulláma, ami Magyarországot is elérheti. Ha ez bekövetkezik, igyekezni fogunk a vizsgálatokat tovább folytatni erre az esetre is, hiszen a bilogisztikus görbe alkalmas ennek a jelenségnek a leírására is. Az így képződő újabb eredményeket a jövőben egy újabb cikkben szeretnénk szintén publikálni.

\section{4. Összefoglalás}

Több ország (Kína, Olasz ország, Magyarország) koronavírussal kapcsolatos halálozási görbéinek és Magyarországon a fertőzöttek számának görbéjét vizsgáljuk. Mindegyik görbe szigmoid típusú, ezért a vizsgálatukra alkalmazható az EBSYQ görbe-analízis rendszer. A görbéket 2020 január közepe és július közepe között, az országok hivatalosan közreadott adatainak összegyüjtésével hoztuk létre.

A napi adatok alapján kialakuló valóságos görbét Pearl- Reed (logisztikai) és Bertalanffy (növekedési) görbével közelítettük, majd a Fisher-Pry transzformáció segítségével lineáris alakúra hoztuk. A lineáris függvényekre felírt lineáris regressziós koefficiensek értékeinek összehasonlítása azt mutatja, hogy a Pearl- Reed szerinti logisztikai függvény írja le jobban a jelenséget, amit a görbék alakjának szemrevételezése is alátámaszt, hiszen a logisztikai függvény tartalmazza a valós függvények kezdeti fázisában található, exponenciális növekedési részt is. A további vizsgálatokhoz ezért mindegyik görbére a logisztikai függvény szerinti közelítést alkalmazzuk.

Értelmezzük a görbék lefutását, alakját, az egyenletükben szereplő paraméterek jelentését, hatását a görbe lefutására, alakjára. Bemutatjuk, hogy ezek alapján olyan, fontos következtetések vonhatók le a járvány alakulásáról, melyeket a járványügyi szakemberek is hasznosíthatnak az egészségügy várható leterheltségére, a szükséges eszközök mennyiségének megtervezésére, a beszerzések szervezésére 
vonatkozólag. Bár az EBSYQ módszer alkalmas lenne rá, valamint a görbék analíziséből adódó, számszerüen összehasonlítható és minősíthető paraméterek is nagymértékben lehetővé tennék, jelen munkában nem tekintjük célunknak a különböző országok járványügyi tevékenységének, a szakemberek munkájának összehasonlítását, rangsorolását, vagy minősítését, hanem inkább az elörejelezhetöségre, becslésekre, prognózis képzésére irányuló következtetéseket, valamint a görbe paramétereinek a jelenség alakulására vonatkozó jelentéseinek értelmezését tartjuk szem előtt.

Az elörejelezhetőséget illetően fontos következtetés, hogy kizárólag csak a görbe inflexiós pontjának elérése után szabad a jövőbeli alakulásra kijelentéseket, előrejelzéseket tenni, mivel ez előtt a jelenség még nem viseli a telítődéses jelleget, hanem a korlátlan, exponenciális növekedés szakaszában van. Ezeknek az előrejelzéseknek a jósága javítható, ha az inflexiós pont elérése után minél több időt hagyunk eltelni az elörejelzés megtételéig.

Vizsgáljuk a görbék deriváltját és integrálját is, ezen görbék alapján is igyekszünk az eddigiekhez hasonló következtetéseket levonni. A derivált harangszerü alakjából a villamosmérnöki tudomány, vagy a rezgéstan hasonló görbéire vonatkozó jellemzők alapján javasoljuk a járványügyi esetekre vonatkozó görbéknél az esetszámok növekedési sebességére vonatkozóan a szignifikancia faktor bevezetését, ami utalhat a járvány erősségére, a növekedés jelentőségére, az esetszámok jövőbeli nagyságának alakulására is.

Az EBSYQ rendszerben lehetőség van a vizsgált jelenség Lorentz- görbéjének, deriváltjának és integráljának is, ezt a vizsgálatok jövőbeli folytatása során szeretnénk elvégezni. Azonban, mivel a benne szereplö paraméterek, valamint a görbék lefutása, sajátosságaiknak a jelenség tulajdonságaira való hatása és jelentése nehezebben értelmezhető, ez hosszabb vizsgálatokat igényel, amit a jövőben a vizsgálatok folytatásával szeretnénk megvalósítani. A vizsgálatok jövőbeli folytatására egy másik ok lehet az esetleges második hullám megjelenése. Mivel a bilogisztikus görbe alkalmas ennek az esetnek a leírására, vizsgálatára is, ebben az esetben az itt bemutatott vizsgálatokat folytatni szeretnénk a második hullám jelenségeinek analízisével is. Az így adódó további eredményeket egy jövőbeli újabb cikkben szeretnénk majd közreadni.

\section{Köszönetnyilvánítás}

A cikkben ismertetett kutató munka az EFOP-3.6.1-16-2016-00011 jelü „Fiatalodó és Megújuló Egyetem - Innovatív Tudásváros - a Miskolci Egyetem intelligens szakosodást szolgáló intézményi fejlesztése" projekt részeként - a Széchenyi 2020 keretében - az Európai Unió támogatásával, az Európai Szociális Alap társfinanszírozásával valósult meg.

\section{Irodalom}

[1] Szabó, F. J.: Analógia a sport- világcsúcsok története és az evolúciós optimáló algoritmusok iteráció- története között. GÉP 2011, 62(9-10):28-31.

[2] Rézsó, F.: Szigmoid görbék alkalmazása tanulócsoportok eredményeinek vizsgálatához. Multidiszciplináris Tudományok, 2020, 10(3):195-211. https://doi.org/10.35925/j.multi.2020.3.25

[3] Kovács, R.: Biogáz- termelődés kinetikája mikrohullámmal kezelt szennyvíz esetén. LXI. Georgikon Napok, 2019. október 4. pp 7.

[4] Besenyei Á., Bodó, Á.: Hálózatok, járványok és a változás egyenletei. Természet Világa 2017, 148(9):395- 399. 
[5] Dénes, A., Ibrahim, M.A., Oluoch, Tekeli, M., Tekeli, T.: Impact of weather seasonality and sexual transmission on the spread of Zika fever. Scientific Report 2019, 9(1):17055. https://doi.org/10.1038/s41598-019-53062-Z

[6] Szabó, F. J.: Evolutionary based system for qualification and evaluation of group achievements (EBSYQ). International Journal of Current Research 2017, 9(8): 55507-55516.

[7] Szabó, F. J.: Optimumkereső algoritmusok iterációtörténetének vizsgálata. GÉP 2018, 69(4):8285.

[8] Pearl, R.; Reed, L. J.: On the rate of growth of the population of the United States since 1790 and its mathematical representation. Proceedings of the National Academy of Sciences 1920, 6(6):275-288. https://doi.org/10.1073/pnas.6.6.275

[9] Bertalanffy, L.: Principles of theory of growth. In: Fundamental Aspects of Normal and Malignaent Growth. Amsterdam. pp. 137-259, 1960.

[10] Fisher, J. C., Pry, R. H.: A simple substitution model of technological change. Technological forecasting and social change 1971, 3:75-88. https://doi.org/10.1016/S0040-1625(71)80005-7

[11] Törnquist, L. 1981. Collected scientific papers of Leo Törnquist. Research Institute of the Finnish Economy. Series A. ISBN 978-951-9205-74-8, 1981.

[12] Mitscherlich, E. A.: The law of minimum and the law of diminishing soil productivity. (In german). Landwirtshaftliche Jahrsbücher 1909, 38:537-552.

[13] Lorentz, M. O.: Methods of measuring the concentration of wealth. Publications of the American Statistical Association 1905, 9(70):209-219. https://doi.org/10.2307/2276207

[14] Nelder, J. A., Mead, R.: A simple method for function minimisation. Computer Journal 1965, 7:308- 313. https://doi.org/10.1093/comjnl/7.4.308

[15] Meyer, W. B., Turner, B. L.: Changes in land use and land cover: a global perspective. Cambridge University Press, 1994. ISBN 0521470854.

[16] Johns Hopkins University homepage: COVID-19 Dashboard by the Center for Systems Science and Engineering (CSSE) at Johns Hopkins University (JHU). https://gisanddata.maps.arcgis.com/apps/opsdashboard/index.html\#/bda7594740fd40299423467 b48e9ecf6 Legutóbbi felkeresés ideje: 2020 július 14. 